\title{
MODELING AND MANUFACTURING OF GREEN GO-KART
}

\author{
KHALEEL ABDUL HUR ALI ${ }^{1}$, TOUSEEF AHAMAD ${ }^{2}$, \\ B. PURNA CHANDRA SEKHAR ${ }^{3} \&$ P. NARENDRA MOHAN ${ }^{4}$ \\ ${ }^{I}$ M. Tech Student, University College of Engineering \& Technology, Acharya Nagarjuna University, India \\ ${ }^{2,3,4}$ Assistant Professors, Department of Mechanical Engineering, University College of \\ Engineering \& Technology, Acharya Nagarjuna University, India
}

\section{ABSTRACT}

There are many motor sports on the planet. Bikes, Cars, Formula one are cases of them. The drivers in these are extremely experts and precise. They can drive it quick. In any case, there are additionally engine sports which needn't bother with expert drivers and need no awesome speed. The vehicles utilized are likewise extremely modest. Such an engine game is Go-Karting. They look like formula one cars yet it is not as speedier as F1 and furthermore cost is less. The drivers in go-karting are additionally not experts. Indeed, even kids can likewise drive it. Go-karts have 4 haggles little motor. They are broadly utilized as a part of dashing in US and furthermore, they are getting famous in India. Go Karting is a major rage to the Americans and Europeans. It was at first made in United States in 1950s and utilized as an approach to pass spare time. Steadily it turned into a major diversion and different nations tailed it. In India, go-karting is planning to make waves. A hustling track is set up in Nagpur for go-karting and Chennai is furthermore endeavoring to make one. Indian associations are moreover making go-karts in little scale. MRF and Indus engines are the real bodies in karts, and they are putting forth karts between 2 lakh and 3 lakh. Be that as it may, to make go-karts prevalent, the cost must descend.

Sun energy is considered as a standout amongst the most tried and true green answers for the extreme vitality emergency being confronted today. As petroleum derivatives like oil, flammable gas and coal, are running out, individuals are hunting down various approaches to create vitality. Solar power is jumping up as a standout amongst the most relentless sustainable wellsprings of vitality that can be utilized to deliver consistent stream of vitality to power warming apparatuses and furthermore vehicles.

For that, many individuals are attempting to assemble Green Go-kart under 1 lakh and we had likewise respond to the call and make our Green Go-Kart under $95 \mathrm{~K}$. This is a dream come true project. A go-kart simply under Rs. $100000 /$-. So, we are certain that our venture will have an appeal in the business, and furthermore we are planning to get orders from the racer and we are going to participate in different racing events all over India and globally. In this project, engine is replaced by electrical motor, hence no emission, pollutants and zero noise.

KEYWORDS: Solar Energy, Go Kart, Electrical Motor \& Automobiles

Received: Apr 24, 2017; Accepted: May 18, 2017; Published: Jun 05, 2017; Paper Id.: IJMPERDJUN201725

\section{INTRODUCTION}

Every nation focused on go-karting, has grabbed hold as a game, has its own account of how karting came to flourish inside is fringes. As it were, this reality gives a false representation of the pleased legacy every nation feels towards this energizing distraction. Normal recorded association of the different begins of go-karting in every nation, and why go-karting is such a famous game in Europe and the United States is the American airman [16]. 
American fathers were building mechanized soapboxes for their youngsters using old engines, for example, clothes washer engines to control the vehicle. Amid World War II this hobby went up against another measurement as a few American pilots manufactured little vehicles from metal tubes to unwind in their spare time. The man frequently credited with building the primary present day style kart that we relate to today is Art Ingles. Workmanship manufactured race, and was himself one of those American pilots specified before, building karts from metal tubes [2]. In any case, his new creation highlighted a steel undercarriage, semi-pneumatic tires, a West Bend 2 stroke motor, a built controlling framework and chain and sprocket control. He initially exhibited his creation in 1956 in a Super market auto show in Los Angles, and the go kart was conceived! Be that as it may, how did the go kart get its present name and spelling. That can be followed back to an organization named GP Mufflers. This present organization's principals were specialists at manufacturing welded parts, and in the wake of seeing Art Ingles unique creation, made their own particular forms and after that enhanced them. A business craftsman for the organization, in an advertisement alluding to the organization's items, instituted the expression Go Karts. Another organization was shaped to deal with the go kart generation, and it was named Go Kart Manufacturing Co. Inc. A more well-known brand name for the karts was conceived when that same promotion organization built up the item name Dart Karts [17]. This organization thrived from 1958 until 1962, when expanded rivalry from extra fabricates and unchecked deals spending sent the organization into liquidation. From its initial days, gokarting has developed into an energizing, overall engine sports occasion.

Kart' is a standout amongst the most usually utilized vehicles in the word. It is extremely primitive machine found by human being. After Car bike and engine auto are found however the ubiquity and fever of go kart exists due to its effortlessness Mind a productive machine with change over electrical auto control into mechanical control generation transportation as yield [18]. Car is most helpful method for transportation of human from little town to urban communities. Car is most prominent vehicle, since it is modest. Its support is additionally unimportant and its administrations client with zero yield regarding cash. Because of rivalry in market, car organizations are likewise propelling distinctive overhaul auto of Car with speculation of corers of Rupees. This shows there is a colossal market still in presence and it's developing [20].

Advancement of a solar-powered car has been a designing objective since the 1980s. The World Solar Challenge is a semiannual solar power car race, where groups from colleges and ventures contend more than 3,021 kilometers (1,877 mi) crosswise over focal Australia from Darwin to Adelaide. In 1987, when it was established, the victor's normal speed was 67 kilometers for every hour (42 mph) and by 2007 the champ's normal speed had enhanced to 90.87 kilometers for each hour (56.46 mph). The North American Solar Challenge and the arranged South African Solar Challenge are practically identical rivalries that mirror a worldwide enthusiasm for the building and improvement of sunlight based controlled vehicles. A few vehicles utilize solar powered boards for auxiliary power, for example, for aerating and cooling, to keep the inside cool, along these lines lessening fuel consumption[20]. 


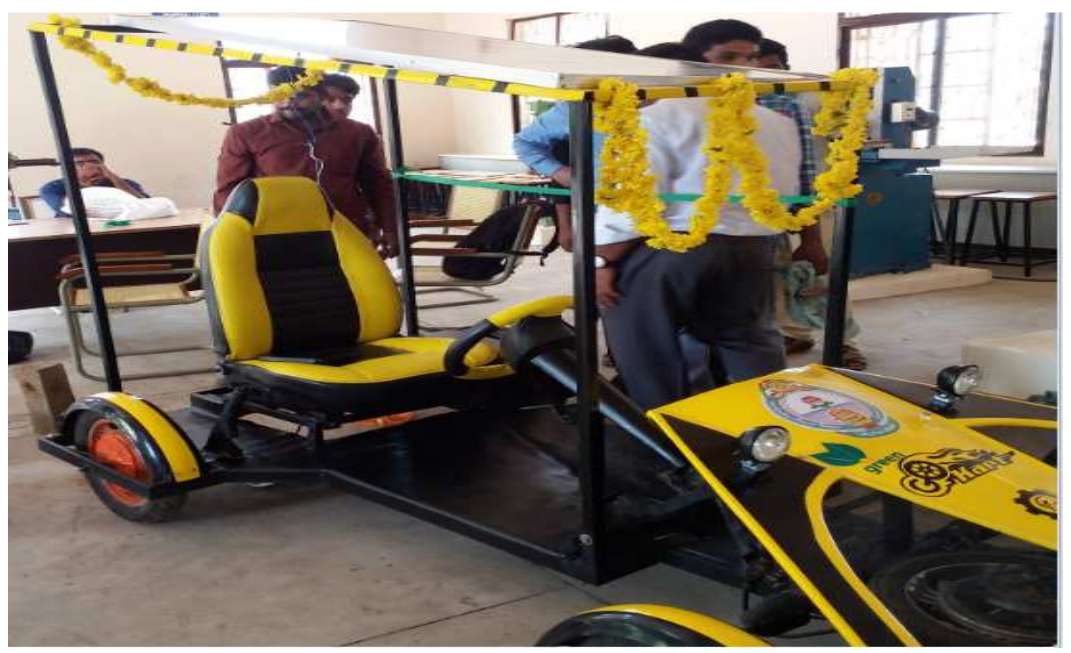

Figure 1: Overall View of Electrical Car

The main purpose was to develop a Green Go kart as shown in Figure 1 that has similar driving characteristics to a usual racing Go karts. Modeling and fabrication of the Green Go-kart concentrates on building up a straightforward, lightweight and effectively worked vehicle. Parts of ergonomics, security, and simplicity of fabricate, and dependability is consolidated into the outline particulars. Investigations are directed on every single real segment to streamline quality and unbending nature, enhance vehicle execution, and to lessen unpredictability and assembling costs. This combined with fitting exploration, to make another case that has enhanced execution and elements. This is finished via conveying static and dynamic examination from hypothetical learning and by testing the Go-kart in genuine situation. A diversion is any choice issue, where the result relies on upon the activities of more than one specialist, and in addition maybe on different certainties about the world. Diversion Theory is the investigation of what reasonable specialists do in such circumstances. Amusements are a sufficiently fascinating class of choice issues that they are deserving of consideration on account of their down to earth importance, regardless of the possibility that they don't clearly shape a characteristic kind.

\section{Components of Green Go Kart}

The kart that we have chosen is a model from Go kart Raising Car due to its specific arrangement of chassis.

\section{Chassis}

The chassis is an extremely imported element of the kart, as it must provide, via flex, the equivalent of suspension to give good grip at the front. Karts have no suspension, and are usually no bigger than is needed to mount a seat for the driver and a small BLDC Motors. Chassis construction is normally of a hollow rectangular bar construction, typically mild steel with different grades. In this kart, we use mild steel rectangular hollow bars with 2" x1"x 3mm dimensions. The chassis support the solar panels, battery, seating etc. The Figure 2 shows chassis modeled in PTC-Creo software. 


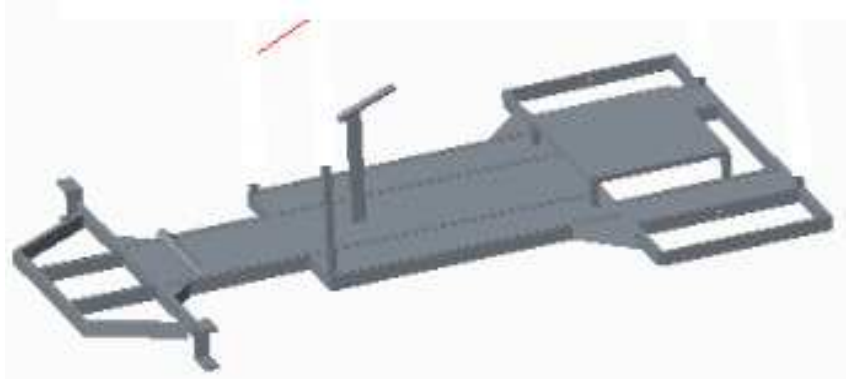

Figure 2: Chassis Modeled in PTC-Creo Software

\section{Rear Wheel BLDC Hub Motor (Brushless Direct Current)}

Keeping in mind the end goal to make the operation more dependable, more proficient, and less boisterous the current pattern has been to utilize brushless D.C (BLDC) motors. They are likewise lighter contrasted with brushed motors with a similar power yield. The brushes in ordinary D.C motors destroy over the time and may cause sparking. This is illustrated in the Figure 3. Accordingly the ordinary D.C motors require occasional maintenance. Controlling the brush sparking in them is additionally a troublesome undertaking.

In this manner the brushed D.C motors ought to never be utilized for operations that request long life and unwavering quality. Therefore and alternate reasons recorded in the presentation, BLDC motors are used as a piece of by far most of the present day devices. Proficiency of a BLDC motors is commonly around 85-90\%, though the regular brushed motors are just $75-80 \%$ productive. BLDC motors are in like manner proper for quick applications (10000 rpm or above). The BLDC motors are additionally outstanding for their better speed control.

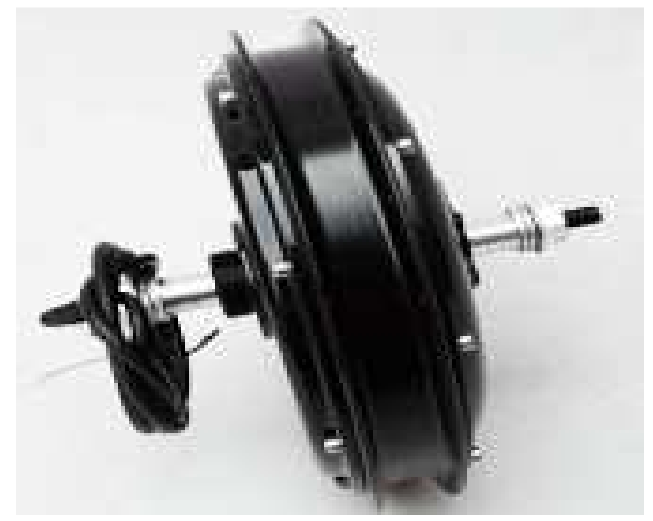

Figure 3: Brushless Motor Hub with $48 \mathrm{~V}$ and $750 \mathrm{~W} / 1000 \mathrm{~W}$ and Net Weight of 6.5kg with Dimensions 20" 24"700C 28" Inch Hub Wheel

\section{Controller}

In a BLDC we utilize an electronic controller unit (ECU) to empower it. A sensor decides the position of the rotor, and in light of this data the controller chooses, which curls to empower. 


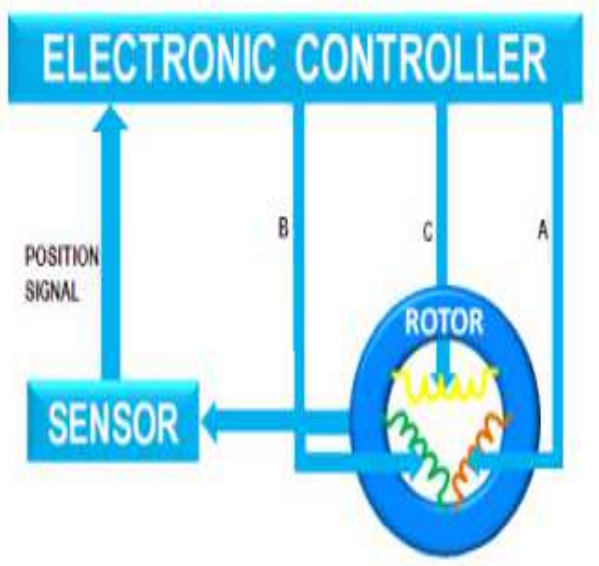

Figure 4: The ECU Determines Which Coil to Energize and When to Energize It

The schematic figure above shows, how the ECU controls errand of invigorating the loop. This undertaking is known as replacement. Regularly, a Hall-effect sensor is utilized for this reason. The Hall-effect sensor is fitted on the back of the motor as shown in the Figure 5

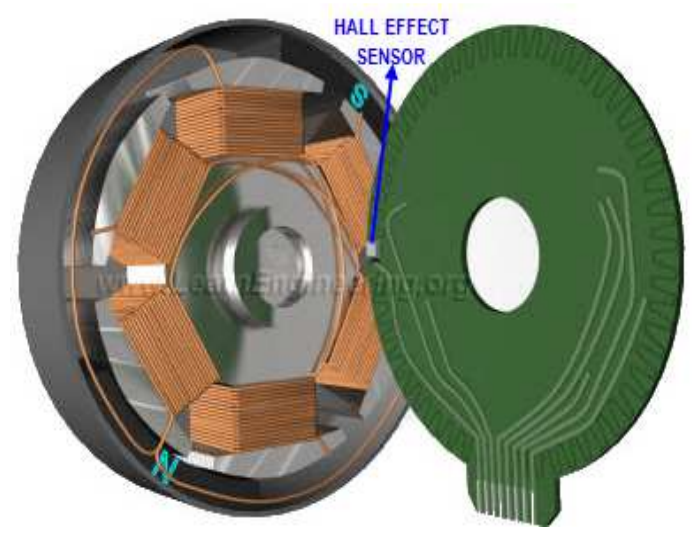

Figure 5: A Hall Effect Sensor is Used to Determine the Position of the Rotor

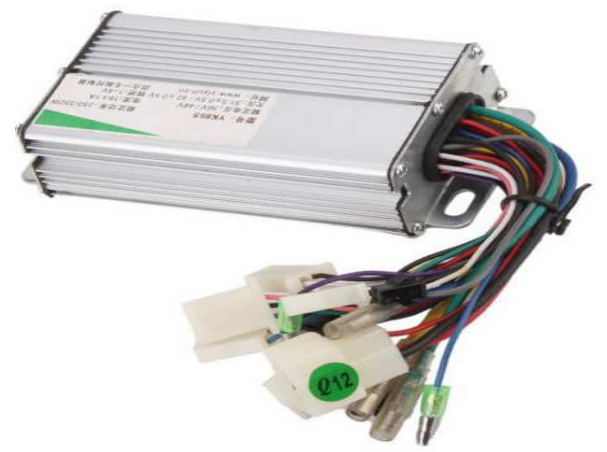

Tyres

Figure 6: 48V 350W Electric Brushless DC Motor Controller

The tyres used for a go-kart often depends on the conditions of the tracks. A wet weather condition would require the use of wet tyres and the slick tyres are used when the weather is dry. Tires that have a direct level of notches on the 
tires to counter with the climate that are in the middle of the wet and dry. Both the wet and intermediate tyres have a full tread patterns which are functioned to expel the water trapped in between the road surface and tyres.

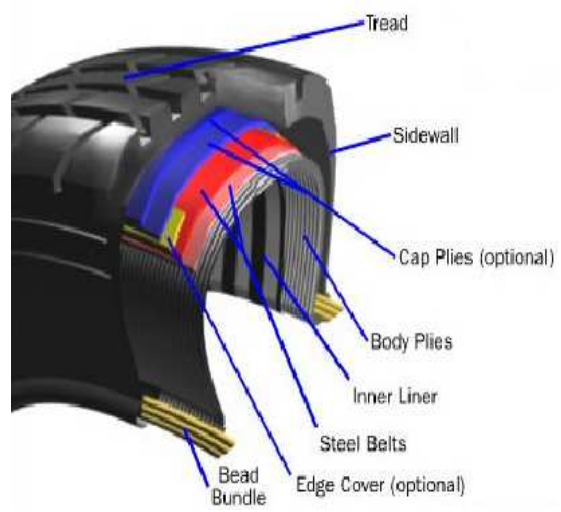

Figure 7: Parts in a Tyre

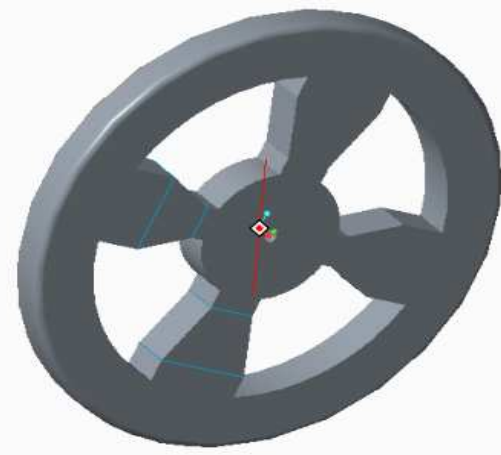

Figure 8: Wheel Modeled in Pro-E Software

\section{Brake}

Brakes are one of the important components in a go-kart. It helps to reduce the speed and stop the go-kart. There are few sorts of brakes framework utilized as a part of the present outline of go-kart. However, the mechanical braking system and the hydraulic braking system system are still the most common braking system being employed in a go-kart.

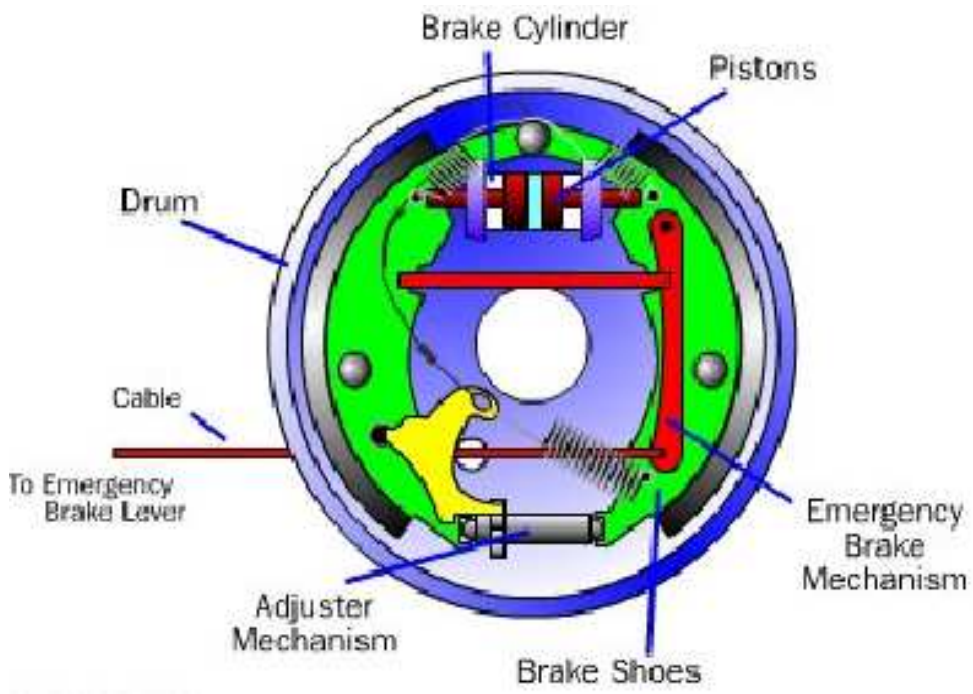

Figure 9: Break

\section{Steering}

According to Go-Kart Guru (2008), the steering systems used in a go-kart include the wagon style steering system and steering knuckle system. The wagon style system is applied in some of the karts, but it is not popular due to its poor performance and impractical to use for high level of competition. Both of the wheels are mounted on an axle and the axle is pivoted in the middle. The whole system will turn together as the wheels are turned. 


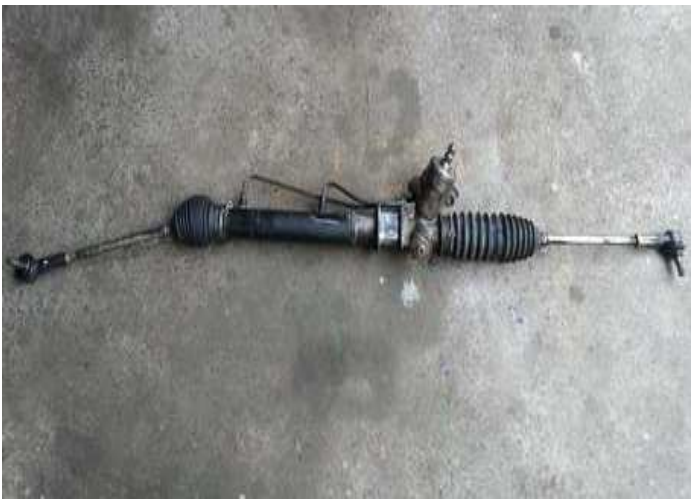

Figure 10: Maruti 800 Steering

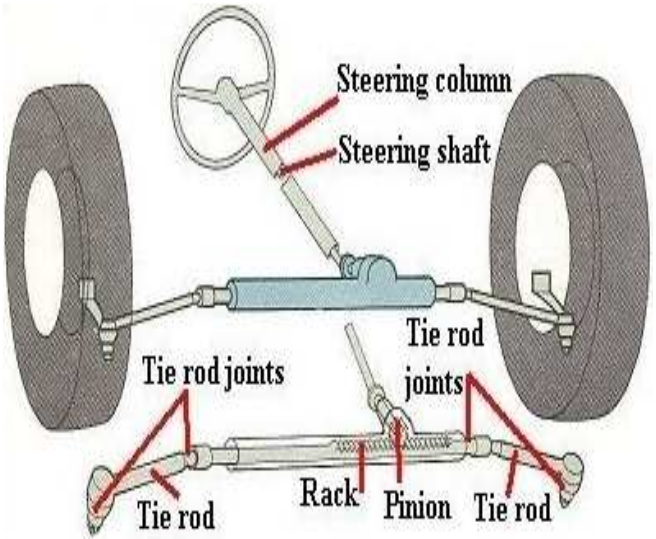

Figure 11: Steering Mechanism

\section{Battery}

Amtek dry e-batteries are used. The specification of the batteries is $12 \mathrm{~V} 24 \mathrm{Amps}$ four batteries are connected in series to obtain the voltage of $48 \mathrm{~V}$

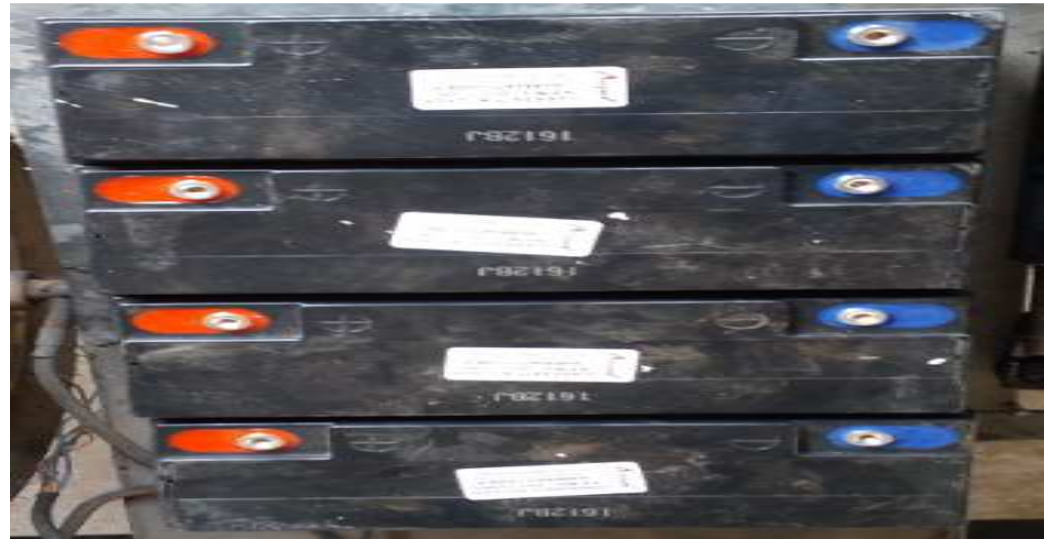

Figure 12: Batteries

\section{Seating}

We are using the front driver seat of innova vehicle, it has multiple motions to move front and back. Back end will be also movable.

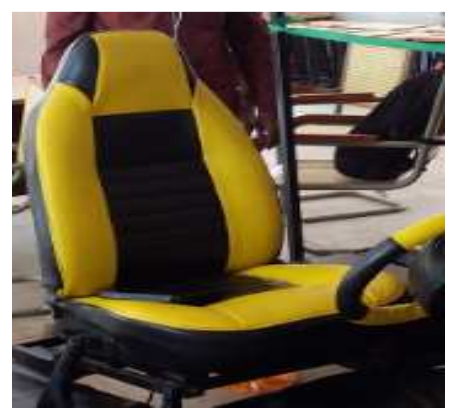

Figure 13: Seat 


\section{Solar Energy}

It is radiant light and heat from the Sun that is harnessed using a range of ever-evolving technologies such as solar heating, photovoltaics, solar thermal energy, solar architecture, molten salt power plants and Artificial Photosynthesis.

\section{Monocrystalline Solar Cells}

This kind of solar cell is produced using slender wafers of silicon cut from misleadingly developed precious stones. These cells are made from single precious stones developed in disconnection, making them the most costly of the three assortments (around 35\% more costly than identical polycrystalline cells), however they have the most noteworthy productivity rating - between $15-24 \%$.

\section{PROBLEM \& DEFINATION}

There is developing interest for non-renewable energy source like diesel and oil to control the automotives and cater different necessities of human. Non-renewable energy sources are being exhausted as a result of their inordinate utilize and restricted stocks. Encourage the utilization of non-renewable energy sources is contaminating nature. In metro urban communities like Delhi, Beijing, level of contamination from vehicles, amid pinnacle hour is unsafe. In light of this individuals are delicate to wear cover for separating the contaminated air for breath. As it is, there are frequent traffic jams conditions out and about because of this there is wastage of fuel and time. Every one of these factors is in charge of different issues in human, for example, cerebral pain, push, diminished execution and so forth. To limit every one of these issues and to keep our earth free from contamination and human wellbeing and wellness, there is a critical need to investigate elective set up of non-renewable energy source fueled vehicles.

Endeavors are being put to create vehicle controlled by solar energy, are some problem associated with out conventional go kart. Car is useful to those people whose daily running with in 50 to $60 \mathrm{Km}$. this hydrogen, biodiesel and batteries. Despite's of above advantages there limitation has maintain use of Car for older age poor class people. As well as driving in out Indian society.

- As a machine in kart some limitation are going to be there. But these can over look by creative thinking, research $\&$ development.

- The cost of fuel is very high.

- Today, the auto industry stands at cross-roads: the increasingly stringent government regulations, a continued reliance on expensive and insecure fossil fuels, and growing concern over global warming, are creating much uncertainty.

- The issue of the depletion of oil reserves in the world, and the problem of air pollution produced by motor vehicles.

\section{SCOPE OF WORK}

The scope of this project work is to

- To study Solar vehicle configuration. i.e. BLDC Motor, Batteries.

- To model and develop solar Green Go Kart by comparing conventional vehicle. 
- Initiate and coordinate the chassis modeling using PTC-Creo software.

- Fabricate the chassis by using welding, bending and sheet metal moulding process for front dome.

\section{OBJECTIVES}

The objectives of the project work are as follow:

- To select and evaluate the optimum model of Green gokart.

- To model and develop a green go-kart with the BLDC Motor which runs with Solar.

- To test dynamically for its performance and suitability of campus use.

- $\quad$ To compare mileage of green go-kart with other vehicle.

\section{METHODOLOGY}

\section{Modeling}

The Go-kart chassis, steering mechanism, wheels and frame for solar panel is modeled using PTC Creo software. The procedure for modeling is given below in detail. The part drawing and finally assembly had done.

\section{Procedure For Part Design}

- $\quad$ Click on file option and choose part.

- Select one of the datum plane i.e., top view, front view, right view and select sketch option.

- Draw the $2 \mathrm{~d}$ profile in the plane by using sketch tools I.e., line, circle, spline, ellipse, mirror etc with accurate dimensions.

- $\quad$ Click on done when the profile is finished.

- Now generate the $3 \mathrm{~d}$ element by using $3 \mathrm{~d}$ tools like extrusion, revolve etc.

- Use chamfer, fillet and hole etc for finishing the element.

- Use the datum plane option to generate the plane either parallel to the reference plane or at an angle to the plane.

- Use the surface of the element as a plane to generate or remove the material.

- Use the tools like variable section blend, sweep, multi sectional sweep and toroidal blend to generate complicated elements.

- $\quad$ Go to file click on save to save it. 

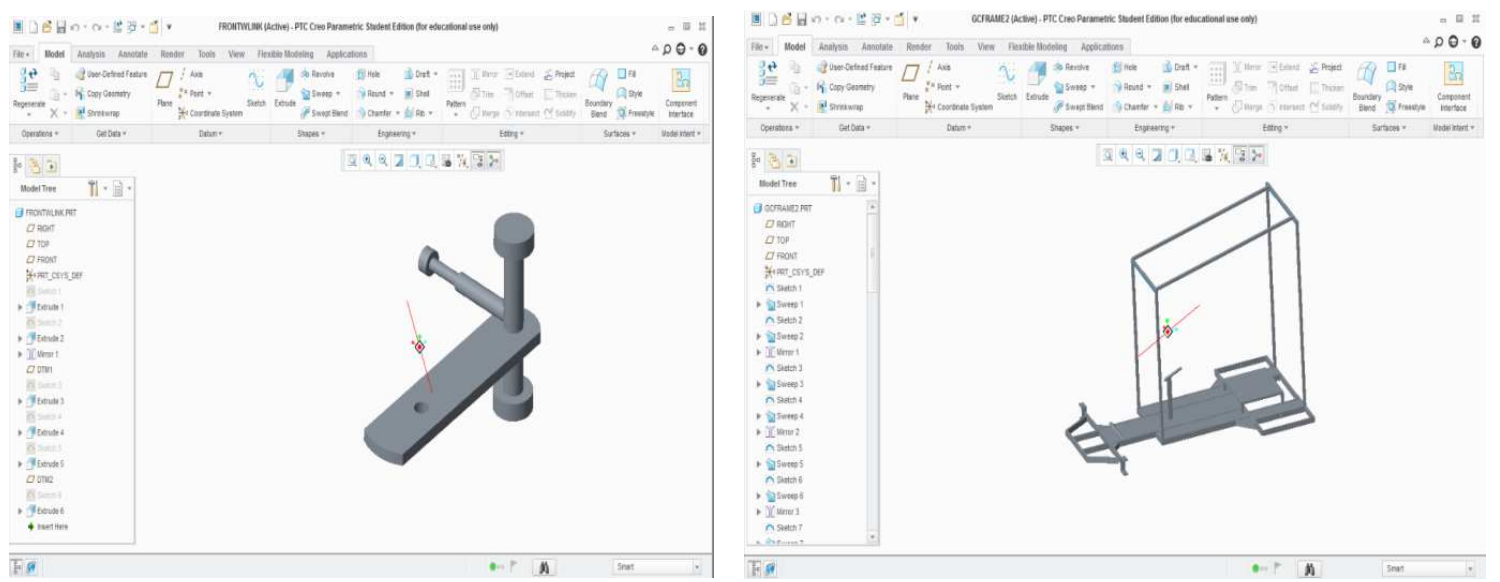

Figure 14: Clamp and Shaft for Steering

Figure 15: Assembly of Chassis and Frame forSolarPanel

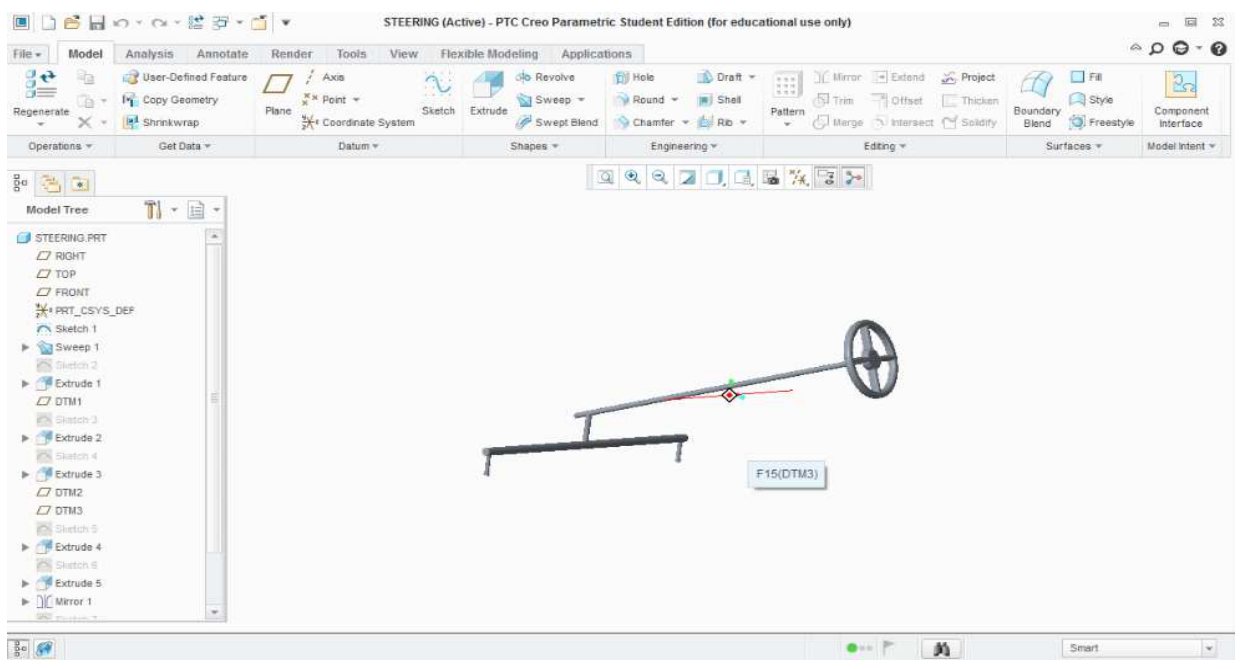

Figure 16: Steering Mechanism

\section{Procedure for Assemble Design}

- Click on file option and choose the assembly option.

- $\quad$ Select the option assembly by predefined parts.

- $\quad$ Select the desired part in the window opened.

- Constraint the part by using option default, align, parallel, normal, coincidence, contact etc.

- Check whether the part is fully constraint or not. If not make it fully constraint.

- Again click on the assemble by predefined parts to assembly the part with the previous parts.

- Make the element fully constraint

- $\quad$ Go to the file and save the current file. 


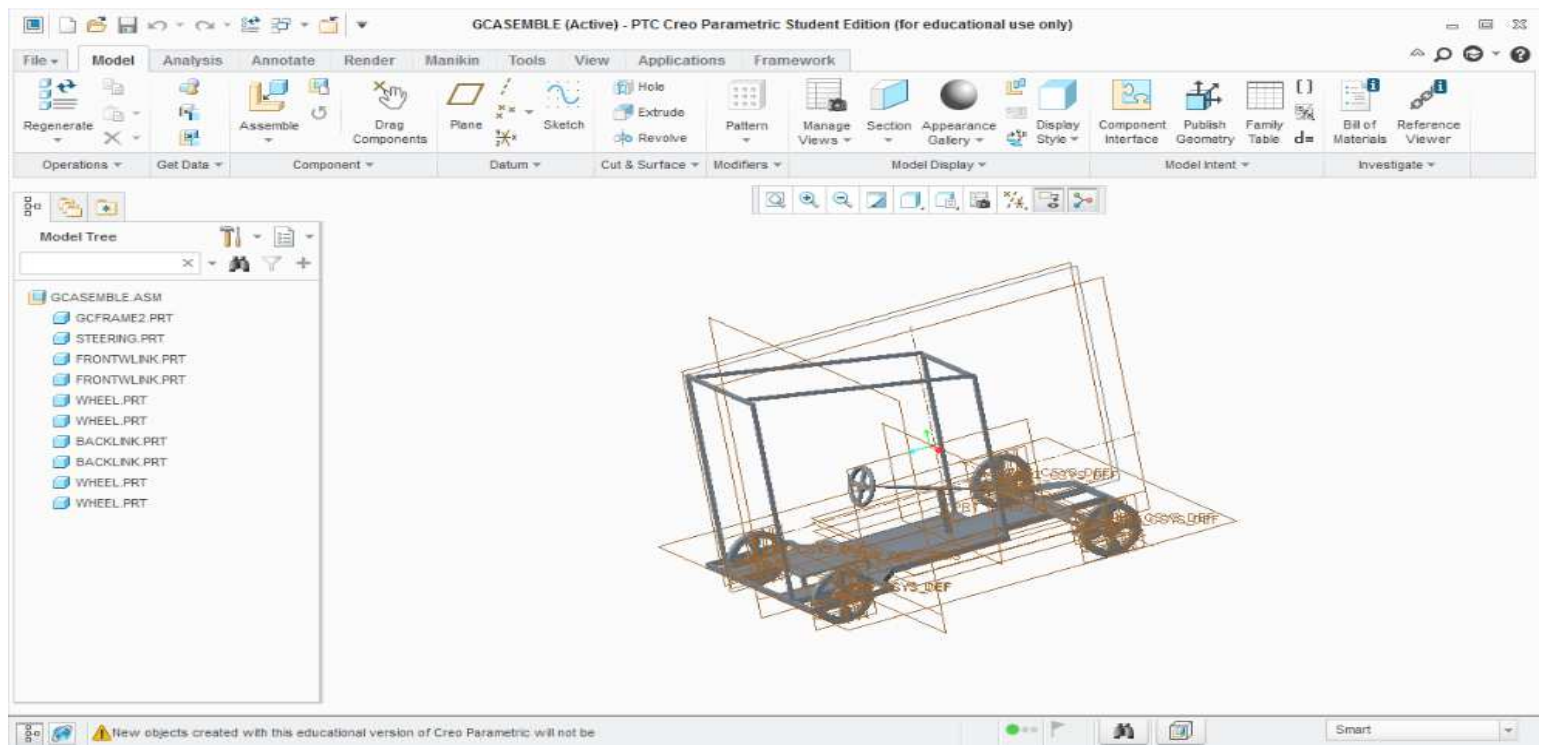

Figure 17: Assembly of Go Kart

\section{Fabrication of Green Go Kart}

For fabrication, we used an Arc Welding, gas welding, gas cutting, grinding and drilling and for Front dome we had used a sheet metal molding. And spray painting is used for painting the go kart.

Initially, we had considered the three long rectangular hollow bars 2 " x1"x 3mm dimensions for fabrication of the chassis as shown in Figure 18. We had cut the bar with cutter in the required dimensions as shown in Figure 18 and welding is done as per the diagram as shown in Figure 15. After the welding is completed the grinding is done for finishing and to remove the unwanted material as shown in Figure 19

The steering mechanism is fixed at the front end of the chassis as show in Figure 20. The bars of the chassis are cut using gas cutter according to the required dimensions to fix the steering mechanism as shown in Figure 20. The wheel are attached to the front and rear end of the chassis.
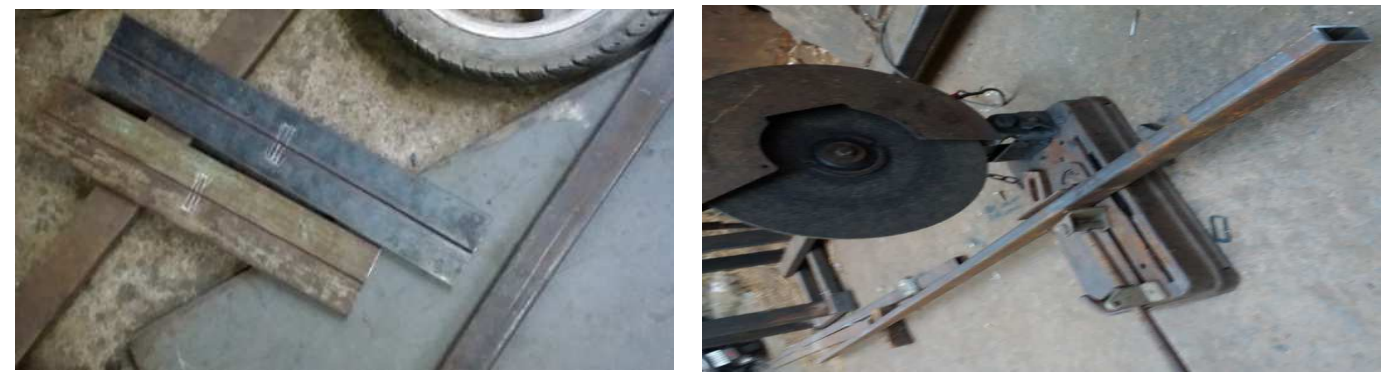

Figure 18: Rectangular Hollow Bars

As the Go kart is eco-friendly, we need to mount a solar panel. For mounting the solar panel a frame is made by considering the 1"x1"x $1 \mathrm{~mm}$ thickness square hollow bars as shown in Figure 21. According to the required dimensions the frame is fabricated by arc welding. And it is assembled to the chassis.

After that the total parts are assembled the batteries, controller etc. are assembled and the go kart is ready as shown in Figure 22. 


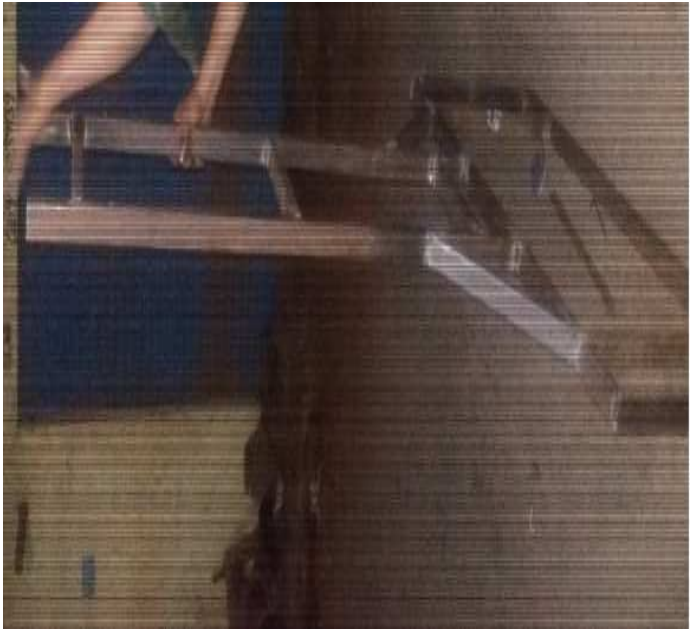

Figure 19: Chassis after Welding

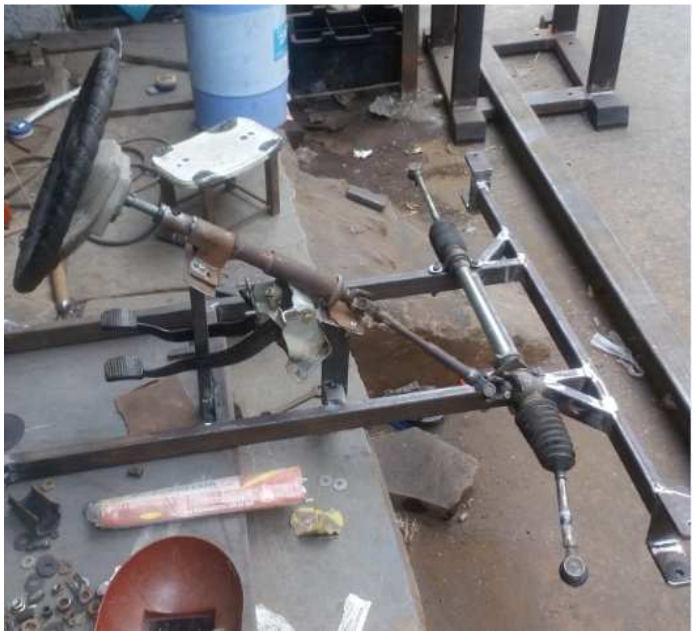

Figure 20: Chassis with Steering Mechanism

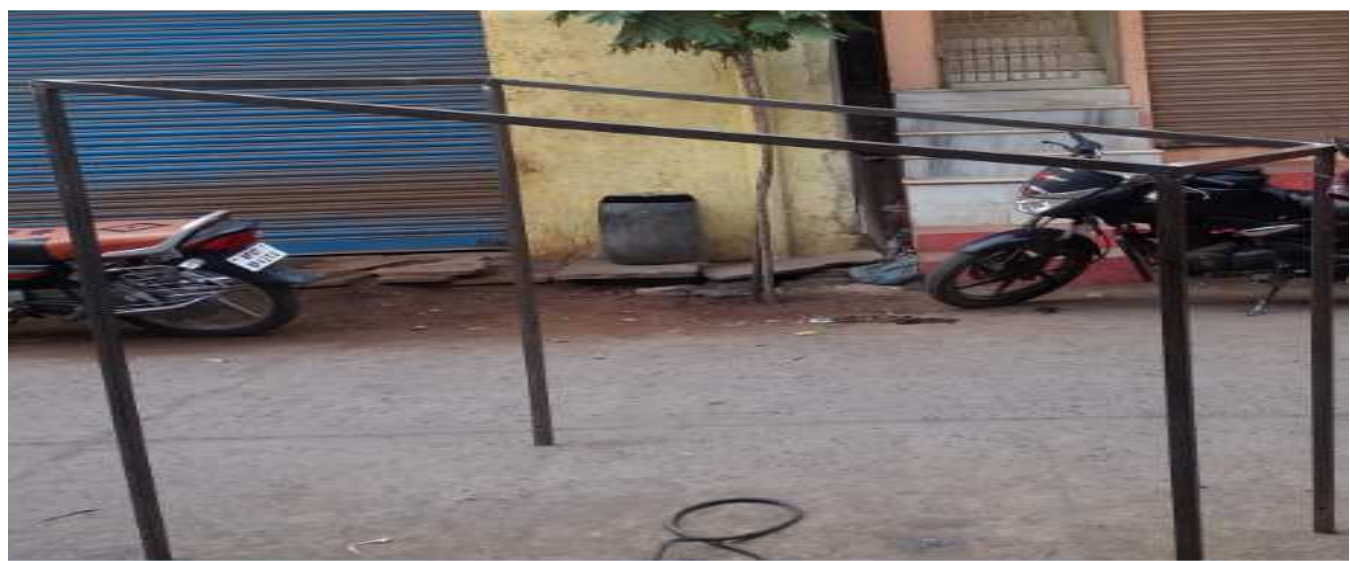

Figure 21: Frame for Solar Panels

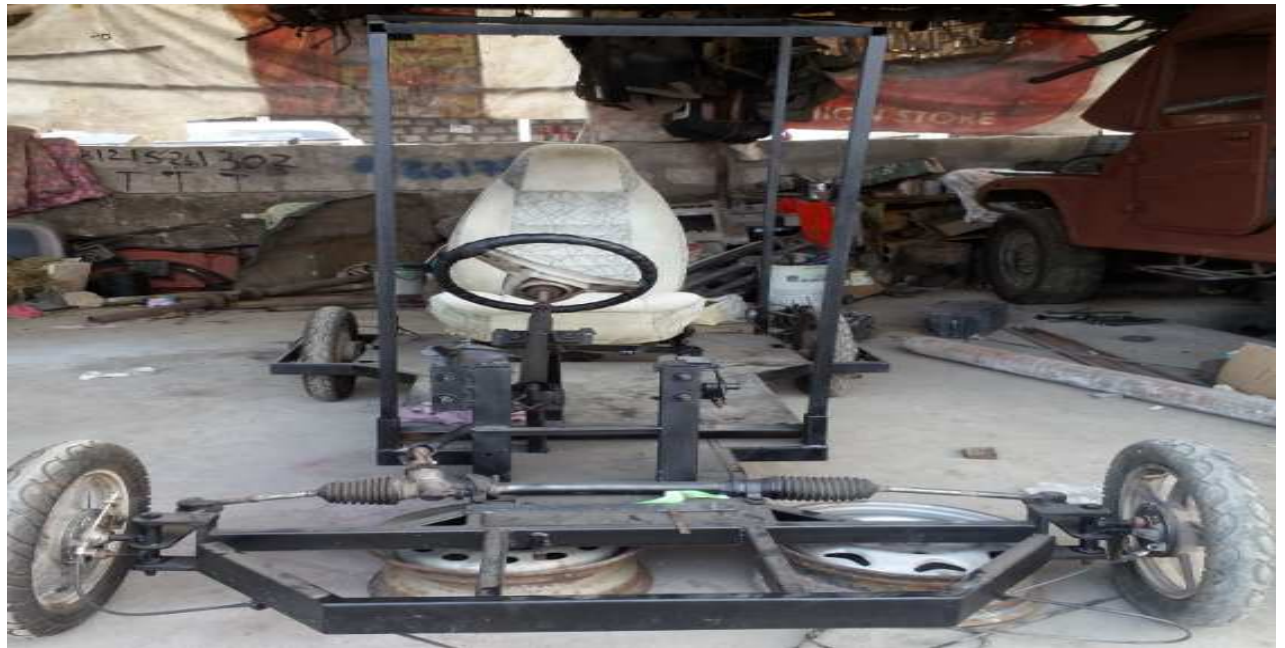

Figure 22: Final Go Kart

For making the kart more stylish, we had made a dome in the front end as shown in Figure 22 with $0.5 \mathrm{~mm}$ gauge sheet and mud guards are attached on the top of the four wheels and for painting we had used a spray painting as shown in 
Figure 22. For matching the colour the seat cover and steering wheel cover is stitched with the matching colour of the gokart. The Electrical work is done i.e. battery, lights, horn, accelerator, controllers, brakes and wiring is done to the kart and leather mat is fixed to the floor of the kart. Stickering is done to make the kart stylish as shown in Figure 22, and finally the solar panel is fixed on the top of the frame.

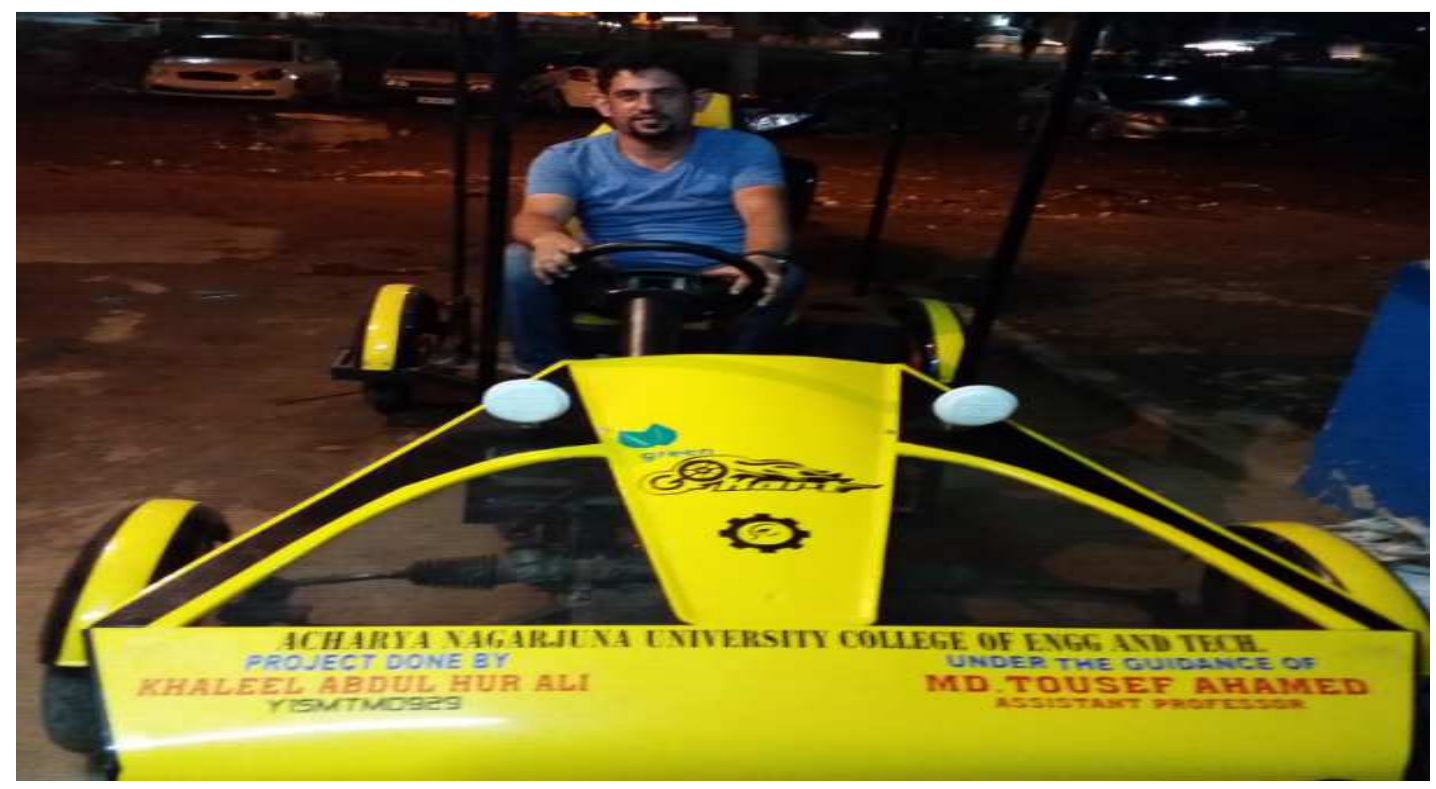

Figure 23: Stickering on the Dome of the Kart

\section{RESULTS \& DISCUSSIONS}

We had referred the literature of fuel economy under three conditions running fully on IC- engine, running fully on electric motor, \& running on combination of both electric and IC-engine (hybrid). In our project, we have used two BLDC series motors of a e-bike as a rear wheels of the vehicle, which has very high speed and it requires a DC $48 \mathrm{~V}$ and 24 Amps battery. We had considered 4 batteries each of $12 \mathrm{~V}$ and 24 Amps are connected in series to gain a voltage of 48V and 24 Amps. This improves the performance and high efficiency and which have low current consumption. The result of mileage of green go kart is $50 \mathrm{Km}$ and it will move with a maximum speed of 50kmph and it will run with solar energy. We have used the straight open kart chassis design. In this project engine is replaced by electrical motors hence no emission, pollutants and zero noise.

For this project, we had used monocrystalline solar panel with 330watt peak, which will give the output of $48 \mathrm{~V}$. The output of the kart is efficient and it will run with zero fuel and zero cost. The chassis is modeled in PTC-Creo software and is fabricated according to the dimensions and its strength is excellent and the front dome, Stickering and painting gives the stylish look to the Green go kart. It was tested dynamically in our campus. 


\section{CONCLUSIONS}

Table 1: Comparison between Conventional and Non Conventional

\begin{tabular}{|l|l|l|}
\hline \multicolumn{1}{|c|}{ Particulars } & \multicolumn{1}{c|}{ Solar Go- Kart } & \multicolumn{1}{c|}{ Go- Kart } \\
\hline Source of power & $\begin{array}{l}\text { Solar panel, BLDC Electric } \\
\text { Motor \& Battery }\end{array}$ & Internal combustion engine \\
\hline P.P. Fuel & Charging by solar energy (Free) & Petrol gasoline (expenses) \\
\hline Initial cost & Low range of Rs. 95, 000. & Low range of Rs.1,50,000. \\
\hline Main Advantage & $\begin{array}{l}\text { Eco-Friendly zero emission, } \\
\text { no pollution. }\end{array}$ & $\begin{array}{l}\text { Cause pollution due to i.e. } \\
\text { terrific emission degradation of } \\
\text { environment. }\end{array}$ \\
\hline Saving of power & $\begin{array}{l}\text { Paring idling we can stop motor } \\
\text { \& i.e. BLDC motor gives } 90 \% \\
\text { efficiency. It runs with solar } \\
\text { energy. }\end{array}$ & $\begin{array}{l}\text { During idling we waste } \\
\text { efficiency } \\
\text { of I.C. engine is 30\%. }\end{array}$ \\
\hline Weight & Low nearly 140 Kg. & Heavy nearly 300 to 400 Kg \\
\hline Economy & 0.25 Rs./Km. & 2.5 Rs. / Km. \\
\hline Maintenance & Negligible \& very cheap & Costly. \\
\hline
\end{tabular}

Finally, we succeed to model and fabricate Solar powered efficient, single passenger green go kart. All the designed components/ systems are safe and performing their intended functions satisfactorily. The Kart travelled a distance of 50 kilometers at a speed of $50 \mathrm{Km} /$ hour in single charging of four hours through solar panel. Thus the aim of the project, i.e. to design and fabricate a competition go-kart while understanding the principles of Chassis designing, Steering System, Caster, Braking systems, Drift, Acceleration, Top speed, Performance tuning, Limitations in practical fabrication. This kart is eco friendly, zero noise and zero air pollution.

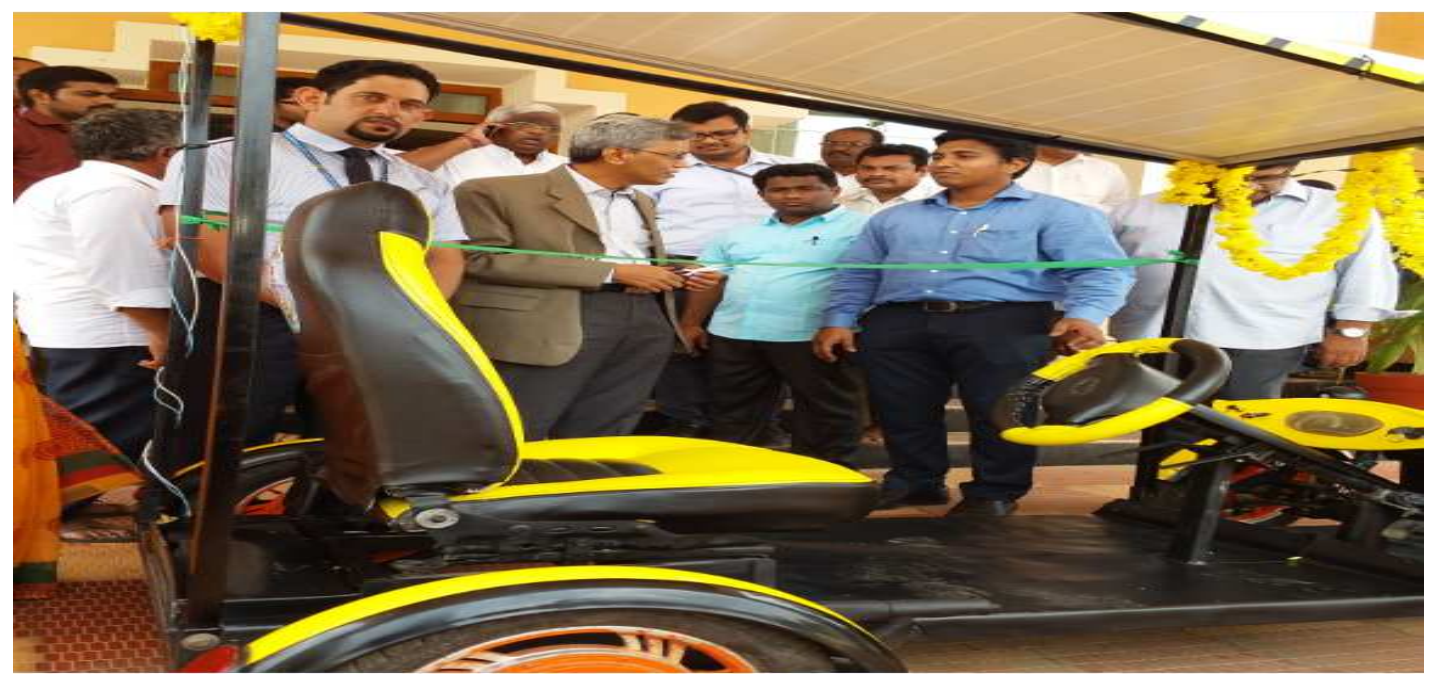

Figure 24: Inauguration of Green Go Kart by University Authorities

\section{FUTURE SCOPE}

The Green Go Kart is very feasible eco-friendly kart for day-to-day travel similar to motorbike. The Kart is much comfortable, which supports the driver for easy riding. Mileage proficient vehicle in correlation with whatever other four wheelers. Very Less weight compared to a small car and comparable to a motorbike. It provides better safety than a two wheeler vehicle. By using a solar panel and good battery and powerful motor, we can make a typical kart which drives with 
motor in city and on highway. In cities, cars have speed around 40-45 km/ hour. And, our green go kart motor is capable to drive kart at this speed and due to this exhaust gases emissions can be reduced in cities, and this is helpful for health and also for global warming.

Now-a-days, hybrid vehicles use Ni-MH battery innovation, which needs substitutions after some period, however rather than these Lithium-ion batteries, which are exceptionally dependable can be utilized. New inventions of lighter but stronger materials like carbon fibers, HSP (high strength polymers), etc. can help in reducing the overall weight of the kart and thus smaller sized high efficiency engines can be used. In future, we can add multi seated Green go kart with solar panels to the mix, with the electrical kart becomes incredibly economical. The cost such as the fuel, maintenance, insurance and other expenses related to running and maintaining the vehicle can be reduce.

Let us say, if we are using four set of battery in kart, which will manufacture, replace and reduce it to one and gain a voltage of $48 \mathrm{~V}$ recharge by using a modified circuit, which will be the future scope. And also, developing the self driving kart is the future revolution.

\section{ACKNOWLEDGEMENTS}

Authors are greatful to University College of Engineering \& Technology, Acharya Nagarjuna University and authorities of the Acharya Nagarjuna University for providing financial assistance to carried out this research work. Thanks to all the students, technicians and faculty who are involved in this project.

\section{REFERENCES}

1. Prof. Kusekar S. K., Bandgar P.M., Andhale P. S., Adlinge G. H, Gaikawad V. V., Dhekale S. P., Design and Development of Electrical Car, International Journal of Emerging Technology and Advanced Engineering, ISSN 2250-2459, ISO 9001:2008 Certified Journal, Volume 5, Issue 4, April 2015, pp 239-251.

2. Budynas R. G., Nisbett Jones J. K., Shigley's Mechanical Engineering Design J $9^{\text {th }}$ edition, McGrawHill., New York., pp. 7 1126

3. Development and assembly of a go-kart sized fuelcell research vehicle by Wegert Daniel, Mauer Christian, Körner Matthias, Altschaffel Florian, Daum Henrik, Klein Sebastian, Karlin Jörg of University of Applied Sciences Bingen, Germany, F2008SC-037

4. Design and fabrication of a go-kart vehicle with improved suspension and dynamics, a project report by Prabhudatta Das, 2010A4PS660G

5. Beer, F. P., Johnston, E. R. Jr., Eisenberg, E. R., Vector Mechanics for Engineers: Statics 8th edition, McGrawHill., New York., pp. $286-304,2007$.

6. Gere B. J., Goodno B. J.,Mechanics of Materials 7 edition\|, Cengage Learning., Toronto., pp. 454 - 513, 2009.

7. Hibbeler R. C.,Engineering Mechanics Dynamics 11 edition\|, Pearson., Jurong, pp. 385 - 441, 2007.

8. Miller, Samuel Wylie (1916). "Oxy-acetylene Welding". The Industrial press.

9. Jeffus, Larry F. (1997). Welding: Principles and Applications (4th, illustrateded.). Cengage Learning. ISBN 978-0-8273-82404.

10. Basic Mech Engg,3E Tnc Syllb. Tata McGraw-Hill Education. 2000 p. 106. ISBN 9780074636626.

11. Swift, P.; Murray, J. (2008). FCS Welding L2. Pearson South Africa. p. 286. ISBN 978-1-77025-226-4. 
12. Automotive Mechanics-William H Crouse C.Fernández, O.García, etal., Hardware and Software Environmenfor Self-learning in Power Electroni10th International Power Electronicsand Motion Control Conference, EPPEMC 2002 - Croatia, September, 2002. Book Reference

13. Automobile engineering - Dr. Kirpal Singh.

14. Automobile Eigneering - Nirali Prakashan.

15. Theory of Machines- SS Rathan Web Reference

16. www.wikipedia.com

17. www.kartbuilding.net

18. www.gokart.com

19. www.ehow.com

20. www.google.com

21. www.teambhpblog.com 